\title{
The discursive ethos
}

\author{
Maria da Glória Corrêa di Fanti ${ }^{1}$ \\ Liz Feréz \\ ${ }_{1}^{1}$ Pontifical Catholic University of Rio Grande do Sul (PUCRS), Porto Alegre, State of Rio Grande do Sul, Brazil. \\ ${ }^{2}$ Paris VIII University, Center for Studies on Media, Technology and Internalization, Paris, France.
}

$\mathrm{T}$ he notion of discursive ethos has been the subject of research on the image of the enunciator produced by the discourse. This image, according to Maingueneau $(2005,2006,2008,2014)$, is built in the discourses through its multiple relations with the others (subjects and speeches) and it emerges from the articulation between various elements (verbal and nonverbal, ethical and aesthetic etc.), which need the interlocutor's incorporation to be apprehended in a complex set of social and cultural representations. ${ }^{1}$

The notion of discursive ethos, although it differs from the notions offered by the rhetorical tradition, does not fail to be in agreement with three fundamental ideas of the Aristotelian ethos: the ethos is (a) a discursive notion, that is, it is constituted through discourse, thus not constituting "an image of the speaker exterior to the speech", (b) an "interactive process of influence over the other" and (c) a "hybrid (social-discursive) notion, having a socially evaluated behavior, which should not be grasped outside a precise communication situation", characteristic of a historical social context (MAINGUENEAU, 2006, p. 60).

In the discursive perspective, there is in each text a voice that can be related to the "characterization of the body of the enunciator" constructed in the discourse (MAINGUENEAU, 2006, p.61). The ethos covers not only the verbal dimension, but also a set of psychic and physical characteristics associated with a guarantor, which is revealed by means of a tone attesting what he says. The guarantor thus receives a character and corporality that will vary according to the constitution of the texts, the scene of the created word. While "character corresponds to a bundle of psychological traits", corporality is linked

\footnotetext{
${ }^{1}$ Some of the ideas about ethos were developed in the article Identidade, alteridade e cultura regional: a construção do ethos milongueiro gaúcho (DI FANTI, 2009).
}

to a "physical complexion and a way of dressing" (MAINGUENEAU, 2006, p. 62).

In addition to character and corporality, the ethos "... implies a way of moving in the social space, a tacit discipline of the body, apprehended by the behavior" (MAINGUENEAU, 2006, p.62). The incorporation of the interlocutor, according to this approach, is not done by the simple identification of a guarantor character, but by its implication in "an ethical world" which, according to the discourse analyst, functions as a diffuse set of social and cultural representations, which highlights the distance between the desired ethos and the real elaborate one.

Amossy (2010), in addressing the issue of ethos and verbal identity, observes that the speaker produces in the discourse a diversity of self-images revealing facets of his identity. And these characteristics of identity can also project group representations, in which the individual appears as "the representative of a collectivity and in which the discourse can appear as a set of interrelated voices" (AMOSSY, 2010, p. 211). Thus, the presentation of oneself in the discourse can refer both to groups that do not yet have clear lines, as well as to groups recognized in the social space, wishing, for example, to be recognized by their identity or to assert themselves through power relations.

The presentation of oneself in speech, which confers authority to the speaker, allows, to varying degrees, on the one hand the emergence of affinities and closeness to certain individuals, as well as, on the other hand, the emergence of distinctions and detachments. Understanding the image that is constructed in discourse, both individual and collective, according to Amossy, involves reflections on the previous ethos and the discursive ethos. While the first (ethos) presupposes knowledge of the speaker's mode of being, the second (discursive ethos) requires the observation of the speech by which the speaker projects an 
image of himself and negotiates his identity (AMOSSY, 2010 , p. 212). For the author, there is no way to dissociate one instance from the other because the speaker in the speech refers to previous data, redefining them. In the negotiation of the construction of the self-image, the speaker dialogues with what others say and think about him.

The present dossier, upon opening the way to the debate on the scope, the challenges and the potentialities of the notion of discursive ethos, brings together in this edition of Letras de Hoje a series of articles focusing on production, circulation and reception of different discourses in society. The article by Dominique Maingueneau, which opens this issue, develops a critical reflection on the notion of discursive ethos, from his contribution, since the 1980 s, to the development of this matter. His reflection takes into account the diversity of the manifestations of the discourse, the process of construction of the ethos and the close relationship between the verbal and the iconic dimensions. To justify his considerations, he analyzes the ads of websites and advertisements. His work is followed by Maria Cecília Pérez Souza-e-Silva and Decio Rocha's article, which discusses the interrelationship between scenography and Maingueneau's ethos.

Articulating theoretical and practical reflections, most researchers consider in their articles the analysis of speech circulating on the internet and/ or social networks, like Juan Manuel López Muñoz and Tamiris Machado Gonçalves, Cristina Rothier Duarte and Francisco Vieira da Silva, Bianca Assis Oliveira de Paula, Fabio Sampaio de Almeida and Maria Cristina Giorgi, Eliane Davila dos Santos and Gislene Feiten Haubrich, and Ernani Cesar de Freitas and Luis Henrique Boaventura.

Analyzes of speeches published in magazines are carried out by Luciana Salazar Salgado and Marina Delege, Elaine Cristina Fonseca, and Luana Ferreira de Souza. In the cultural field, the reflections are presented by Hélène Barthelmebs-Raguin, Lia Raquel Vieira de Andrade and Juliana Georgia Gonçalves Araújo. In the field of telephone recording, Welton Pereira e Silva works on the issue of false kidnapping. Advertisement is handled by Silma Ramos Coimbra Mendes and Edgar Godoi Gabriel.

We are grateful to the authors of this issue for their important collaboration and invite the academic community to join on the reflections developed here.

\section{References}

AMOSSY, R. (Org.). La présentation de soi. Ethos et identité verbale. Paris: PUF, 2010.

DI FANTI, M. G. C. Identidade, alteridade e cultura regional: a construção do ethos milongueiro gaúcho. Alfa: Revista de Linguística (UNESP. Online), v. 53, p. 149-166, 2009.

MAINGUENEAU, D. Retour critique sur l'éthos. Langage et société, v. 149, n. 3, p. 31-48, 2014.

MAINGUENEAU, D. A propósito do ethos. Tradução de Luciana Salgado. In: MOTTA, A. R.; SALGADO, L. (Org.). Ethos discursivo. São Paulo: Contexto, 2008.

MAINGUENEAU, D. Cenas da enunciação. Organizado por Sírio Possenti e Maria Cecília Pérez de Souzae-Silva e tradução de Sírio Possenti. Curitiba: Criar, 2006.

MAINGUENEAU, D. Ethos, cenografia, incorporação. In: AMOSSY, R. (Org.). Imagens de si no discurso: a construção do Ethos. Tradução de Dílson Ferreira da Cruz, Fabiano Comesu e Sírio Possenti. São Paulo: Contexto, 2005.

\section{Organizers}

(D) MARIA DA GLÓRIA CORRÊA DI FANTI < gloria.difanti@pucrs.br>

Professor-researcher at PUCRS and PQ/CNPq Scholarship.

(D) LIZ FERÉ <info@lizfere.com>

Professor-researcher at Paris VIII/ CEMTI University. 